\title{
Examination of Traffic Congestion and Remedial Measures, Coimbatore City
}

\author{
S.D.Anitha Selvasofia, G. Prince Arulraj, V.G.Srisanthi
}

\begin{abstract}
During the past few years, there has been high growth of demand for road transportation.The volume of road traffic has increased continuously over years due to the increase in the vehicle population, buying power, rented cab services, increasing economy activities and urbanisation. Road accidents and traffic congestion impose a burden on the society. Reducing the traffic congestion and road accidents are very important for efficient road transportation. With the increase in population in Coimbatore, the number of vehicles also increased. An effort has been made to study the traffic volume of Avinashi Road NH47, Trichy Road, NH81, Sathy Road NH209, Mettupalayam Road NH67 and Other Corporations Road. The vehicle population in Coimbatore has increased at an alarming rate. In the year 2014-15, around 27100 two wheelers, 4800 cars and 1800 other transport vehicles have been registered. In the year 2015-16, 33000 two wheelers, 6700 cars and 3040 other vehicles have been registered. The increase in the percentage comes to $20 \%, 40 \%$, $40 \%$ respectively during the years 2014-15, 2015-16. Coimbatore has a large number of floating population. The traffic on its roads has increased so much that it often becomes very difficult to cross a road. During the peak hours of the day, we find an unending stream of buses, trucks, cars, tempos, scooters, motor-cycles and cycles are seen in many roads. Most of the drivers of the vehicles do not observe traffic rules. Other than this, accident data opinion survey was also carried to know the problems faced by the pedestrians. After analyzing all the data, remedial measures such as widening of road, removal/ relocation of bus stops, implementation of speed brakers and introduction of manned and unmanned traffic signals are suggested in the study area. An overall analysis was carried out to determine the effects of introducing the remedial measures. It is found that the traffic congestion can be reduced if the remedial measures are implemented.
\end{abstract}

Key Words: Accident study, Traffic volume, Traffic congestion, manned traffic signals, traffic signals

\section{INTRODUCTION}

Transportation plays a vital role in everyday life. Traffic congestion not only affects the nation's economy but also has an physiological effect on the road users. In addition, congestion will increase pollution and accelerates the process of global warming. With the rapid growth of urban traffic, the capacity of the roads have reached the saturation limit and traffic congestion has become in stable. Identifying the frequently congested road sections, estimating their influence on the entire road network, improving the connectivity and accessibility of the whole road network through local traffic

Revised Manuscript Received on December 30, 2019.

S.D.Anitha SelvaSofia,AP(Sr.Gr), Department of Civil Engineering, Sri Ramakrishna Engineering College. Coimbatore, India

Dr.G. Prince Arulraj, Department of Civil Engineering

Karunya Institute of Technology and Sciences, Coimbatore, India

Dr.V.G.Srisanthi, Department of Civil Engineering

Coimbatore Institute of Technology, Coimbatore, India reformation, have become important issues to transportation planners and managers. Traffic congestion can be characterized by the decrease in speed, the increase in travel time and the increase of vehicle's queue on the road. In addition, traffic congestion happens when the road demand exceeds the road capacity. Establishing an effective traffic congestion analysis and monitoring the evolvement of congestion state and making appropriate suggestions will provide strong support to transportation management and planning.

\section{A. Risk Zone}

Risk zone is the zone where the occurrences of accidents are repetitive and the level of risk is high. To identify the risk zone, highest accident rate and a major cause of accident in these zones are studied.

\section{B. Geographic information system}

GIS makes it possible to integrate different kinds of geographic information, such as digital maps, aerial photographs, satellite images and global positioning system data (GPS), along with associated tabular database information (e.g., 'attributes' or characteristics about geographic features).Using GIS, you can incorporate all of this information into a single system and execute common database operations. For example, GIS allows you to perform statistical analysis or spatial queries, to explore 'what-if' scenarios, and to create predictive models.

\section{C .Benefits of GIS}

GIS benefits organizations of all sizes and in almost every industry. There is a growing awareness of the economic and strategic value of GIS. The benefits of GIS generally fall into five basic categories:

Cost saving and increased efficiency

Better decision making

Improved communication

Better record keeping

Managing geographically

GIS application in transportation

GIS-T is one of the leading GIS application fields.

Many GIS-T applications have been implemented at various transportation agencies and private firms. They cover much of the broad scope of transportation and logistics, such as infrastructure planning and management, transportation safety analysis, travel demand analysis, traffic monitoring and control, public transit planning and operations, environmental impacts assessment, intelligent transportation systems (ITS), routing and scheduling, vehicle tracking and dispatching, fleet management, site selection and service area analysis, and supply chain management. 
Examination of Traffic Congestion and Remedial Measures, Coimbatore City

Each of these applications tends to have its specific data and analysis requirements. For example, representing a street network as centerlines may be sufficient for transportation planning and vehicle routing applications. A traffic engineering application, on the other hand, may require a detailed representation of individual traffic lanes.

\section{II.STUDY AREA}

Coimbatore corporation lies between the latitude and longitude of $11^{\circ} 1^{\prime} 6^{\prime \prime} \mathrm{N} 76^{\circ} 58^{\prime} 21^{\prime \prime} \mathrm{E}$ It is located on the banks of the Noyyal River, in south western part of Tamil Nadu at an elevation of $411 \mathrm{~m}$ above mean sea level. It covers an area of 287.2893 sq.km. As there is a huge availability of employment in the city, the people from adjoining cities and states enter the Corporation area and the $\mathrm{NH}$ roads are designed for the people to pass through the city which results in heavy traffic congestion. The study area is shown in figure 1 .

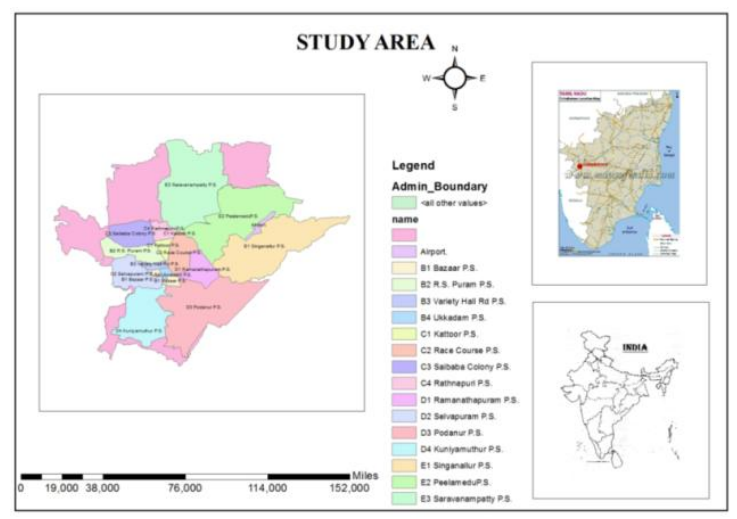

Fig 1. Study area

\section{OBJECTIVES OF THE STUDY}

The study has been carried out with the following objectives

$>$ To identify the accident risk zones using overlay analysis

$>$ To identify the zones prone to traffic congestion.

$>$ To suggest solutions to minimize the traffic congestion and accidents.

$>$ To estimate the reduction in the risk zones in the study area after implementation of the proposed suggestions.

\section{IV.DATA COLLECTION}

The accident data for the years 2010-2016 for Coimbatore city were collected from the police department. The accidents were classified into three types namely (i) accidents without injury (safe), (ii) accidents that caused injury and (iii) accidents that resulted in death. The details of the accidents are given in Table I

Table-I Classification of Accidents

\begin{tabular}{|l|l|l|l|}
\hline Year & Safe & Injury & $\begin{array}{l}\text { Human } \\
\text { loss }\end{array}$ \\
\hline 2010 & 8 & 8 & 19 \\
\hline 2011 & 83 & 90 & 155 \\
\hline 2012 & 217 & 196 & 370 \\
\hline 2013 & 249 & 239 & 421 \\
\hline
\end{tabular}
reduced.

\begin{tabular}{|l|c|c|c|c|}
\hline Year & 2 Wheeler & 4 Wheeler & Heavy Vehicle & Pedestrian \\
\hline 2010 & 10 & 13 & 5 & 7 \\
\hline 2011 & 129 & 108 & 37 & 54 \\
\hline 2012 & 259 & 354 & 71 & 99 \\
\hline 2013 & 424 & 251 & 122 & 112 \\
\hline 2014 & 596 & 291 & 160 & 151 \\
\hline 2015 & 359 & 252 & 288 & 174 \\
\hline 2016 & 244 & 213 & 62 & 72 \\
\hline $\begin{array}{l}\text { Tota } \\
1\end{array}$ & 2021 & 1482 & 745 & 669 \\
\hline
\end{tabular}

From the Table, it can be seen that $41 \%$ of the accidents are caused by two Wheeler, $30 \%$ of accidents are caused by four wheeler, $15 \%$ of accidents are caused by heavy vehicle and $14 \%$ of accidents are caused by pedestrians. By limiting the speed of two wheelers and four wheelers, by providing pathways for pedestrians and by diverting heavy vehicles through ring roads, the number of accidents can be

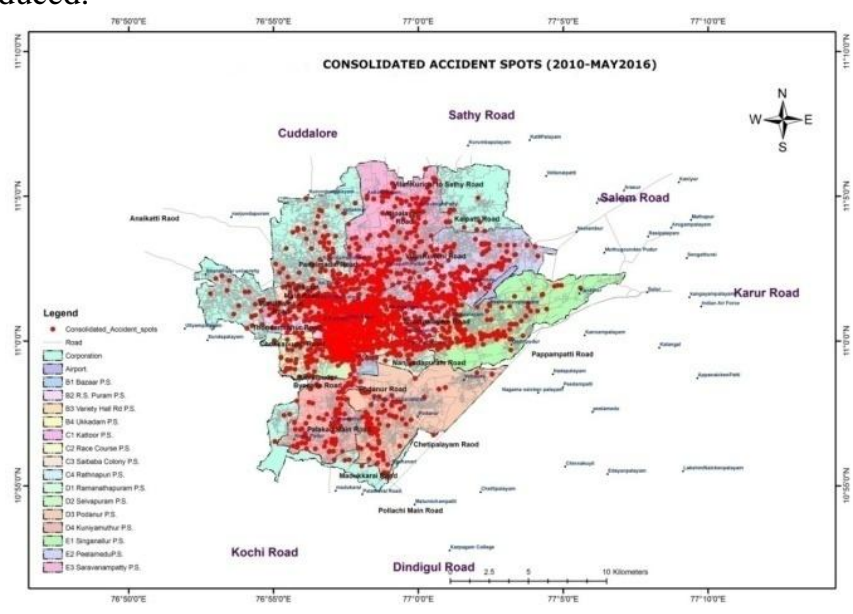

Fig 2. Consolidated Accident Spots

From the Figure 2, it can be seen that majority of the accidents have taken place very close to the centre of the city.

The details of the traffic volume data that have taken place during the peak hour and non peak hour are given in TableIII. 
Table-III Traffic Volume Data

\begin{tabular}{|c|c|c|c|c|c|c|c|c|c|c|}
\hline \multirow[t]{3}{*}{ Place } & \multicolumn{10}{|c|}{$\begin{array}{c}\text { Traffic Volume data } \\
\text { Passenger Car unit (PCU) }\end{array}$} \\
\hline & \multicolumn{2}{|c|}{ Bus /Truck } & \multicolumn{2}{|c|}{ Car } & \multicolumn{2}{|c|}{ Auto } & \multicolumn{2}{|c|}{ Two Wheeler } & \multicolumn{2}{|c|}{ Cycle } \\
\hline & $\mathrm{PH}$ & $\mathrm{NPH}$ & $\mathrm{PH}$ & NPH & $\mathrm{PH}$ & $\mathrm{NPH}$ & $\mathrm{PH}$ & $\mathrm{NPH}$ & $\mathrm{PH}$ & NPH \\
\hline Saravanampatti & 884 & 2210 & 4596 & 11490 & 300 & 750 & 5200 & 13000 & 25 & 46 \\
\hline SRPMills & 564 & 1410 & 4120 & 11501 & 275 & 687.5 & 4800 & 12000 & 24 & 53 \\
\hline Ganapathy & 750 & 1875 & 5000 & 13251 & 241 & 602.5 & 5300 & 13250 & 33 & 63 \\
\hline Sai Baba Kovil & 550 & 1375 & 3850 & 9865 & 200 & 500 & 9421 & 23550 & 40 & 69 \\
\hline Thudiyalur & 495 & 1237 & 4600 & 10510 & 198 & 495 & 8425 & 21061 & 32 & 54 \\
\hline GowndanPalayam & 368 & 920 & 2950 & 7375 & 175 & 437 & 7950 & 19875 & 41 & 56 \\
\hline Lakshmi Mill & 1165 & 2912 & 8023 & 20057 & 595 & 1487 & 8595 & 21488 & 55 & 61 \\
\hline PSG Tech & 1350 & 3375 & 9500 & 23750 & 600 & 1500 & 9000 & 22500 & 23 & 39 \\
\hline $\mathrm{KMCH}$ & 1250 & 3125 & 10500 & 26250 & 623 & 1557 & 9623 & 24055 & 49 & 55 \\
\hline West Club & 690 & 1725 & 4700 & 11750 & 490 & 1250 & 6250 & 15625 & 51 & 63 \\
\hline Singanallur Junction & 750 & 1875 & 4836 & 12090 & 493 & 1236 & 6300 & 15750 & 62 & 73 \\
\hline Sulur & 650 & 1625 & 4900 & 12250 & 485 & 1135 & 5293 & 13234 & 56 & 60 \\
\hline
\end{tabular}

PH- Peak Hour, NPH-Non-Peak Hour

Table III gives the details of volume of traffic during Peak Hours (PH) and Non Peak Hours (NPH). These data were obtained after carrying out traffic survey for a month. 8.00 am to 10.00 am and $1.00 \mathrm{pm}$ to $2.00 \mathrm{pm}, 4.00 \mathrm{pm}$ to 6.00 $\mathrm{pm}, 8.00 \mathrm{pm}$ to $9.00 \mathrm{pm}$ were considered as peak hours.

From the above Table, it can be seen that the traffic volume is high in almost all places. However, the taffic volume is found to be high near, Lakshmi mills junction, PSG College of Technology, KMCH, and Sai baba kovil. Also from Table 3 it can be seen that the number of accidents are high in Avinashi road and Mettupalayam road. Larger traffic volume has represented in more accidents. Hence suitable measures are to be taken in highways to reduce the traffic congestion. If ring road is formed then the buses, trucks and other vehicles which needed not have to come to the city also use inner city roads. Hence diverting the vehicles through the ring roads will reduce congestion and accidents of city. The following factors are considered to reduce the traffic congestions.

$>$ Number of lanes

$>$ Road category

$>$ Land use and Land cover

$>$ Traffic volume data

Bus stops

\section{V.OVERLAY ANALYSIS}

Overlay Analysis Has Been Carried Out To Identify the Zones Prone To Congestion Giving the Weightages Given In Table IV.

Table-IV Factors Considered for Traffic Congestion with Possible Weights

\begin{tabular}{|c|c|c|c|}
\hline S.No & $\begin{array}{l}\text { Factors } \\
\text { affecting } \\
\text { occurrence } \\
\text { of } \\
\text { accidents }\end{array}$ & $\begin{array}{l}\text { Possible } \\
\text { variations }\end{array}$ & $\begin{array}{l}\text { Weights } \\
\text { assigned } \\
\text { for } \\
\text { Separate } \\
\text { analysis }\end{array}$ \\
\hline \multirow{2}{*}{1} & \multirow{2}{*}{$\begin{array}{l}\text { Number of } \\
\text { lanes }\end{array}$} & Two lane & 2 \\
\hline & & 4 lane, 6 lane & 1 \\
\hline \multirow{4}{*}{2} & \multirow{4}{*}{$\begin{array}{l}\text { Road } \\
\text { Category }\end{array}$} & ODR & 1 \\
\hline & & MDR & 2 \\
\hline & & $\mathrm{SH}$ & 3 \\
\hline & & $\mathrm{NH}$ & 4 \\
\hline \multirow{5}{*}{3} & \multirow{5}{*}{$\begin{array}{l}\text { Land use } \\
\text { and Land } \\
\text { cover }\end{array}$} & $\begin{array}{l}\text { Agriculture and } \\
\text { Water Bodies }\end{array}$ & 1 \\
\hline & & Barren Land & 2 \\
\hline & & Open Land & 3 \\
\hline & & Commercial & 4 \\
\hline & & Residential & \\
\hline
\end{tabular}




\begin{tabular}{|c|c|c|c|}
\hline \multirow{4}{*}{4} & \multirow[b]{4}{*}{$\begin{array}{l}\text { Traffic } \\
\text { Volume }\end{array}$} & Low & 1 \\
\hline & & Medium & 2 \\
\hline & & High & 3 \\
\hline & & Very High & 4 \\
\hline \multirow{3}{*}{5} & \multirow{3}{*}{ Bus stops } & $<0.5 \mathrm{~km}$ (high) & 3 \\
\hline & & $0.75 \mathrm{~km}$ (Medium) & 2 \\
\hline & & $>0.75 \mathrm{~km}$ (Low) & 1 \\
\hline
\end{tabular}

The results of the overlay analysis are shown in Figure 3

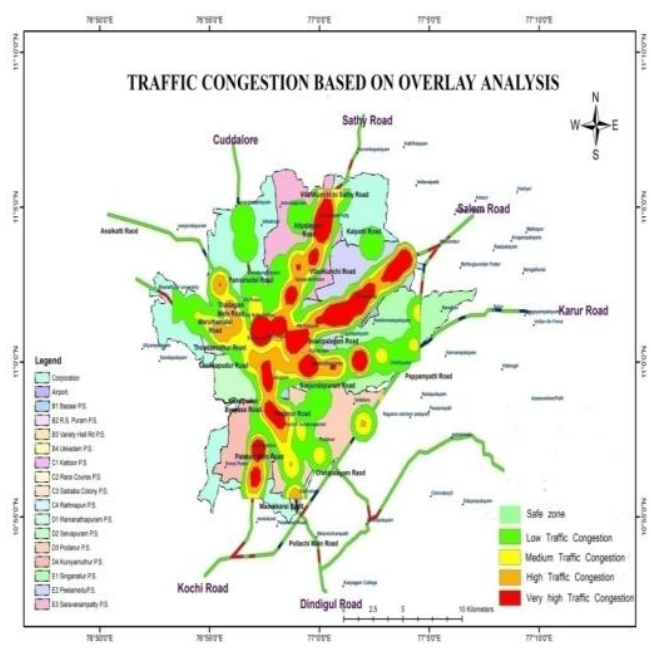

Fig 3 Traffic Congestion in National Highway

\& State Highway based on overlay analysis

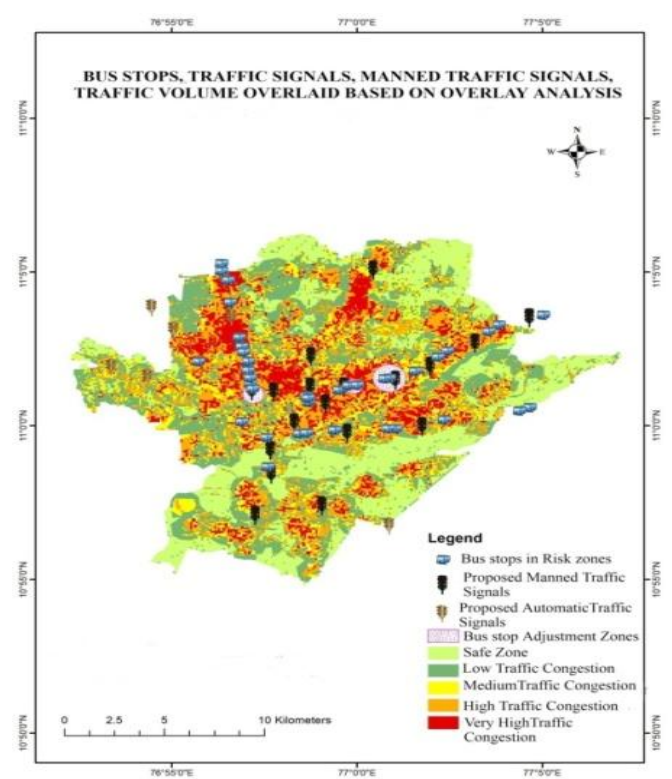

Fig 4 Bus stops, Traffic signals, manned traffic signals,

Traffic volume overlaid based on overlay analysis.

Figure 4 shows the bus stops located in very high congested zones. It also gives the proposed traffic signals required in the very highly congested and highly congested zones.

It can be seen from Figure 4 that, along the place of congestion, many bus stops, bus stops near traffic signals, bus stops near intersections are seen which cause traffic congestions. In order to reduce the traffic congestion, few bus stops were removed, few were relocated, few automatic and manned traffic signals were introduced.

\section{VI.RESULT AND DISCUSSIONS}

Based on the overlay analysis, 17 places have been identified as accident prone zones and the proposed remedial measures are given in Table $\mathrm{V}$. 


\section{Table- V: Remedial Measures}

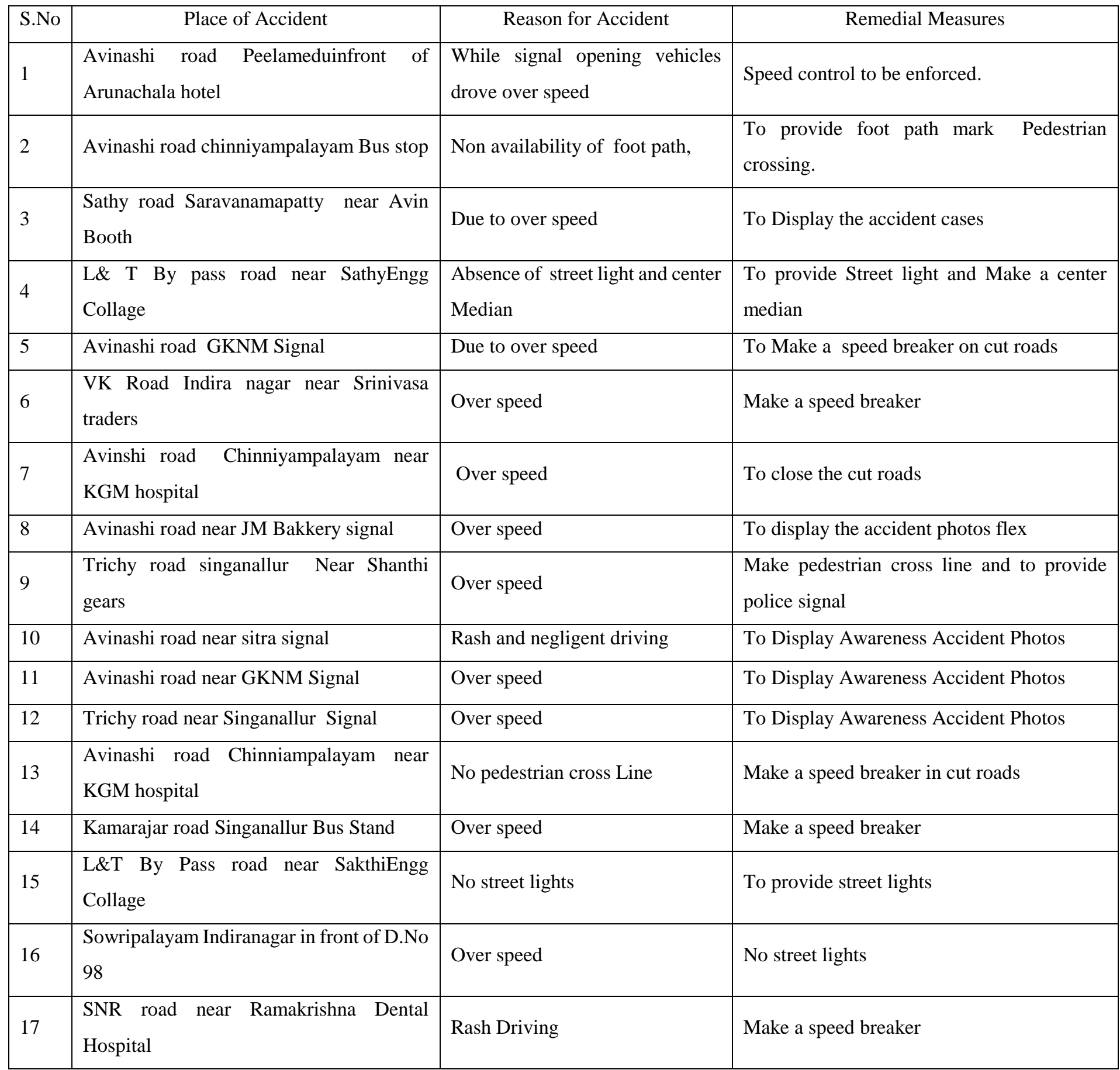

\section{CONCLUSION}

Effective management of traffic flow will ensure safe and secured the traffic movement. The population of Coimbatore is increasing due to the presence of major educational and industrial institutions. As a result recently the population in the city rose. Existing city road network is not adequate to the needs of the increasing traffic volume. There are so many road intersections in Coimbatore city road network. There are no separate lanes for slow moving vehicles as due to which the problems like traffic congestion delay and road accidents occur at the major road intersection in Coimbatore city. The accident locations and suggested some possible alternative or corrective measures were given to improve the transportation system in these locations, from which the decision maker can select suitable measure for the location. The method is found to be effective in identifying the black spots, provided sufficient secondary data is available.

\section{REFERENCES}

1. Anitha Selvasofia S.D, Nithyaa.R \& Prince Arulraj.G 2013 , 'Minimizing the Traffic Congestion Using GIS' in IJREAT International Journal of Research in Engineering \& Advanced Technology, Volume 1, no. 1, ISSN 2320 - 8791.

2. Ardeshir Faghri \& Khaled Hamad, 2002, 'Application of GPS in Traffic Management Systems, GPS Solutions volume 552. https//doi.org/10.1007/PL00012899 
3. Banik B.K, Chowdhury M.A.I, Hossain E \& Mojumdar B 2011, 'Road Accident \& Safety Study' in Sylhet Region of Bangladesh in Journal of Engineering Science And Technology vol. 6, No. 4, pp. 493 - 505.

4. Blazquez \& Celis 2013, 'A spatial \& temporal analysis of child pedestrian crashes in Santiago, Chile' Accident Analysis \& Prevention Volume 50, pp. 304-311.

5. Brian L. Smith, M. Asce, Ling Qin \& Ramkumar Venkatanarayana.2003. 'Characterization of Freeway Capacity Reduction Resulting from Traffic Accidents', Journal of Transportation Engineering,Volume 362

6. Carola A.BlazquezMarcela S.Celis 2013,' A spatial \& temporal analysis of child pedestrian crashes in Santiago, Chile', Accident Analysis \& Prevention, Volume 50, pp. 304-311.

7. Daniel Shefer, Piet Rietveld, 1997 Congestion \& Safety on Highways Towards an Analytical Model, https//doi.org/10.1080/0042098975970 vol 34, no. 4. pp. 679-692.

8. David C. Eckley, Kevin M. Curtin,2013 'Evaluating the spatiotemporal clustering of traffic incidents', Computers, Environment \& Urban Systems, Volume 37,pp. 70-81

9. Debasish Chakraborty, Debanjan Sarkar, Shubham Agarwal, Dibyendu Dutta \& Jaswant R. Sharma, 2015 'Web Based GIS Application using Open Source Software for Sharing Geospatial Data', Cloud Publications International Journal of Advanced Remote Sensing \& GIS, Volume 4, no. 1, ISSN 2320 - 0243, pp. 1224-1228.

10. Deelesh Mandloi \& Rajiv Gupta, 2003 'Evaluation of accident black spots on roads using Geographical Information Systems (GIS)' Map India Conferenceat GIS development.net, file///C/Users/sofia\%20 samuel/Downloads/Evaluation_of_accident_black_spots_on_roads_u sing_.pdf

11. Deepthi Jayan.K \& B.Ganeshkumar, 2010 'Identification of Acciden Hot Spots' in A GIS Based Implementation For Kannur District, Kerala ' In International Journal of Geomatics And Geosciences Volume 1, No

12. Duc Nguyen Huu \& Chon Le Trung,2012 'Open Source Softwares In Building Webgis of Bus Information System', International Symposium on Geoinformatics for Spatial Infrastructure Development in Earth \& Allied Sciences.

13. Elke Moons, Tom Brijs, 2009, 'Spatial Modelling of Risk In Traffic Safety On The Road Network', Association for European Transport \& contributors,pp. 1-16.

14. Erdogan, S., Yilmaz, I., Baybura, T., Gullu, M. 2008, 'Geographical Information Systems Aided Traffic Accident Analysis System Case Study City of Afyonkarahisar', Accident Analysis \& Prevention, vol. 40/1, pp. 174-181.

15. Fatih Keskin, Firdes,Yenilmez, MithatÇolak.Ipek, Yavuzer.H SebnemDüzgün, 2011 'Analysis of traffic incidents in METU campus' Procedia - Social \& Behavioral Sciences, Volume 19,pp. 61-70.

16. Ganeshkumar \& D.Ramesh, 2010, 'Emergency Response Management \& Information System (ERMIS) A GIS based software to resolve the emergency recovery challenges in Madurai city, Tamil Nadu' International Journal of Geomatics And Geosciences Volume 1, No 1.

17. Gary A. Davis (001, 'Using Bayesian Networks to Identify the Causa Effect of Speeding in Individual Vehicle/Pedestrian Collisions' 17th Conference in Uncertainty in Artificial Intelligence, University of Washington, Seattle, Washington, USA, pp. 105-111

18. Geurts.K, \& Wets.G, 2003,'Black Spot Analysis Methods Literature Review' http//www.steunpuntverkeersveiligheid. be/sites/default/ files/ RA-2003-07.pdf

19. Ghazan Khan; Xiao Qin,\& David A. Noyce 2008 ,'Spatial Analysis of Weather Crash Patterns, Journal of Transportation Engineering Volume 134 no. 5 .

20. Gill.N \& Bharath B.D, 2013 'Identification of Optimum Path for Tourist Places Using GIS Based Network Analysis A Case Study of New Delhi' IJARSGG, vol.1, No.2, PP34-38.

21. Gourav Goel , S.N. Sachdeva 2014 'Identification of Accident Prone Locations Using Accident Severity Value on a Selected Stretch of NH-1' International Journal of Engineering Research \& Applications (IJERA) ISSN 2248-9622,PP31-34

22. Guler Yalcin \& Sebnem Duzgun.H, (2015) 'Spatial analysis of two-wheeled vehicles traffic crashes Osmaniye in Turkey' KSCE Journal of Civil Engineering, e Volume 19, no. 7, pp 2225-2232

23. Hamby.B,\& Thompson.K. 2006. New toolkit provides practical tools to build better bus stops. ITE Journal 76 (9) PP22-26.

\section{AUTHORS PROFILE}

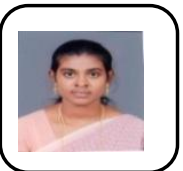

Anitha Selvasofia completed her U.G Degree in Civil Engineering in the year 2004 in Karunya Institute of Technology, Coimbatore. She completed her M.E Geo-Informatics in the year 2007 at College of Engineering, Guindy. She obtained her Ph.D. Degree on 'Identification of accident prone zone and minimizing the traffic congestion flow using GIS' in 2019 under Anna University, Chennai. She has published 11 papers in International Journals and 2 papers in International Conference and 3 papers in National conferences. She has organized 2 National Conferences. At present she is working as Assistant Professor (Sr.Gr) at Sri Ramakrishna Engineering College, Coimbatore .
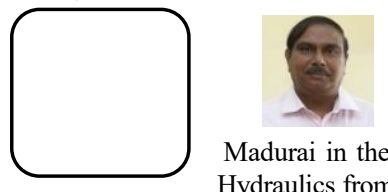

Dr. G. Prince Arulraj completed his Bachelor's degree in Civil Engineering at Thiyagaraja College of Engineering, Madurai in the year 1982 and got his Master's degree in Hydraulics from IIT Madaras in the year 1984. He secured First Rank in Thiyagaraja College of Engineering, Madurai and Second Rank in Madurai Kamaraj University. He obtained his Ph.D. degree in the year 1999 from IIT Madras. He is a Member of various professional bodies like Indian Society of Technical Education, Indian Water Resources Society, Geotechnical Society of India, etc. He has 32 years of experience in teaching, administration and research. He has held various responsibilities such as Head of the Department, Vice-Principal, Principal, Dean, Controller of Examinations, etc. At present, he is the Dean for Engineering \& Technology at Karunya Institute of Technology and Sciences, Coimbatore. Dr. Prince Arulraj has more than 170 publications in Conferences, National Journals and International Journals He has organized many Faculty Development Programs, Workshops, Seminars and Conferences. He has successfully completed many consultancy assignments to a tune of about 50 crores.

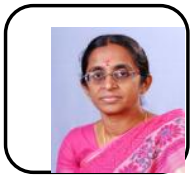

Dr.Srisanthi completed her Bachelor's degree in PSG College of Technology, Coimbatore in 1988 and did Masters in Structural Engineering in 1994 at CIT. She obtained her Ph.D. Degree on 'Efficiency of Friction Damper System in Rigid Frames' in 2004 under Bharathiar University. She published papers in International and National Conferences. She is the Life Member of professional Bodies like Institution of Engineers (India), Indian Society for Technical Education, Indian Association of Structural Engineering, Indian Society for Earthquake Engineering, Indian Concrete Institute and Association of Structural Rehabilitation.Dr. V.G. Srisanthi is working as Professor \& Head in department of Civil Engineering at Coimbatore Institute of Technology, Coimbatore, India. She is guiding researchers for their doctoral programmes and projects for under graduate and post graduate students. Dr. Srisanthi has established unique Bi-Axial $(2 \mathrm{~m} \times 2 \mathrm{~m})$ Shake Table in Structural Engineering laboratory for testing of 2D \& 3D structural models under dynamic loading. She has received research grants and funding from various agencies like AICTE (Rs.9.6 Lakh), UGC (Rs.4.3 Lakhs), UNDP (Rs.4.75 Lakhs) and INSDAG (2.5 lakhs). 